\title{
Congress cracks down
}

\section{Washington}

A GROWING number of break-ins, fire bombings and threats by animal-rights extremists is fuelling movement in Congress towards a law that would make crimes against animal-research laboratories a federal offence.

Claiming that state and local police forces are not competent to prevent animal rights attacks on research facilities, several members of Congress have recently introduced bills that would allow the Federal Bureau of Investigation (FBI) and other federal police bodies to investigate crimes by animal activists.

The legislators argue that assaults on animal research laboratories are often planned and executed by national animalrights organizations, and that participants often cross state lines. They note that at least one extremist organization, the Animal Liberation Front, began in the United Kingdom and continues to have ties there. In the past decade, illegal acts by animal-rights organizations have increased more than three-fold, according to statistics compiled by the National Association for Biomedical Research (NABR). In 1989 alone, NABR reports 19 incidents, ranging from sit-ins to bombings. Seven of the more extreme attacks were attributed to the ALF.

Testifying at a hearing on one of the bills last week, Richard Van Sluyters, from the University of California, Berkeley, who has been targeted by animalrights groups, characterized the activists as "professional agitators . . . Their interstate conspiracy is beyond the local lawenforcement ability", he said.

"When you tell a local policeman that someone has taken your rats and written on your walls, they don't understand the level of tragedy", added Robert Phalen, from the University of California, Irvine.

One bill, introduced by Senator Howard Heflin (Democrat, Alabama), passed the Senate late last year, and has been introduced in the House by Representative Charles Stenholm (Democrat, Texas). Another House bill, which was the subject of last week's hearing, has been introduced by Henry Waxman (Democrat, California).

All the bills agree on one point breaking into a federally funded research facility would be a federal felony, and solving the cases would be the responsibility of the FBI, the Justice Department or other federal organizations.

Waxman's bill applies only to laboratories funded by the Public Health Service, which would include all facilities supported by the National Institutes of Health. Heflin and Stenholm's bills apply to any research facility, whether private or publicly funded.
But the three bills will probably have to be modified in some way to gain enough congressional support to pass. Heflin's bill, for example, contains language that would make it a federal offence to photocopy laboratory documents without permission, a clause that has been assailed as unduly harsh. "It's important that we don't make it impossible to be a legitimate whistle-blower", one aide says.

The White House has already stated its opposition to Waxman's bill on legal grounds, and would no doubt oppose the other bills if asked. But in a Democratic controlled Congress, administration opposition is by no means the kiss of death.

Indeed, supporters of the bills believe that some sort of legislation in support of harsher penalties for animal-rights breakins is likely to emerge this year.

G. Christopher Anderson ANIMAL RIGHTS: LITIGATION

\section{Activist group under fire}

\section{Washington}

PEOPLE for the Ethical Treatment of Animals (PETA), an international animal rights group, last week said it would sue for libel over an article in the February issue of Washingtonian magazine that alleges that the organization is financially corrupt and that some of PETA's bestknown publicity photographs were staged.

The 16-page article, entitled "Beyond cruelty", cites anonymous sources who claim to be former PETA financial officers saying that in 1986 PETA used more than 20 separate bank accounts to hide $\$ 1.2$ million in donations that had never been reported as income. The sources also allege the "illegal" use of nearly $\$ 62,000$ of PETA funds to pay for the defence and fine of an Animal Liberation Front member who has been convicted of participating in a 1986 University of Arizona break-in.

Katie McCabe, the article's author, also alleges that one of the photographs that PETA has used to symbolize vivisection in its promotional posters was staged. The photograph of a monkey uncomfortably tied to a steel restraining apparatus was taken by PETA founder Alex Pacheco in 1981 in the Silver Spring, Maryland, laboratory of Edward Taub. McCabe alleges that Pacheco, who posed as an interested volunteer to gain access to the laboratory, and a PETA associate tied the animal to the apparatus themselves in a late-night photo session.

Pacheco categorically denies the allegation that there was anything "staged" about the photograph. He says the monkey was tied to the "chairing" apparatus by three workers at the laboratory as was customary. He had been assigned to observe the animal before it was to be experimented on, during which time he took the photographs, he says, but "in no way, shape or form did I modify the apparatus or the animal's position". Pacheco notes that during legal proceedings against Taub the authenticity of the pictures was never challenged. He also points out that the pictures were taken in the afternoon. Washingtonian editors say an "editing error" incorrectly place the event at night.

The Washingtonian article has received wide praise from many in the scientific community, and drawn equally strong criticism from animal activists. Last week, James Mason, the assistant secretary of the Department of Health and Human Services, the Federal agency that runs NIH, submitted the article in support of his testimony at a congressional hearing on animal activist legislation (see accompanying article). The article, he said, illustrated the "serious problem" of animal rights extremism. "Not only are the extremists threatening the right of research scientists to work without intimidation but also, and more importantly, they are endangering the future of our nation's health", Mason says.

But activists and their supporters claim that the article errs on many key points, and paints the animal-rights community in an unfair light. "This is clearly a vicious article intended to depreciate the animal rights movement," says Philip Hirschkop, an attorney who says he will file a libel suit this week for PETA. The suit will seek damages from both malicious libel (the allegations that Pacheco had faked the photographs) and business libel (the allegations of PETA's illegal financial practices) Hirschkop says.

Although PETA officials concede that they have several bank accounts, they say that Federal deposit insurance only covers up to $\$ 100,000$ per account, thereby forcing them to spread their funds over many accounts. "But all contributions were accounted for and reported to the IRS [Internal Revenue Service]", Pacheco says. G. Christopher Anderson

\section{Eastern Europe: A special issue}

A SURVEY of Science in Eastern Europe, compiled by Alun Anderson, Stephen Dickman and John Maddox, will be published in Nature on 12 April, in place of the planned survey of Science in France originally planned for that date. The French survey will appear on 12 July. 